\title{
Self-assessment via a blended-learning strategy to improve performance in an accounting subject
}

\section{Vanesa Gámiz Sánchez', Rosana Montes Soldado² and María Carmen Pérez López ${ }^{3}$}

\section{Recommended citation}

Gámiz, V., Montes, R. \& Pérez, M.C. (2014). Self-assessment via a blended-learning strategy to improve performance in an accounting subject. RUSC. Universities and Knowledge Society Journal (RUSC), 11(2). pp. 41-54. doi http://dx.doi.org/10.7238/rusc.v11i2.2055

\begin{abstract}
The General Accounting subject is on the curricula of five different bachelor's degrees offered in the Faculty of Economics and Business at the University of Granada (UGR), Spain. In a coordinated way, all the lecturers involved in this subject have generated interactive materials and a methodology that allows students to undertake online self-assessment activities that are very similar to the final exam. Following a blended-learning methodology, General Accounting combines classroom education techniques with the use of information and communication technology (ICT) tools, and the students work to improve their grades. In the 2012/13 academic year, students on two of the degrees were consulted about their overall satisfaction with using this platform. From the results, we can highlight the positive appraisal of the interestingness and usefulness of activities on the platform. We also obtained a positive correlation between the students' access to the activities and the grades obtained in them, and the final grades obtained in the subject.
\end{abstract}

\section{Keywords}

higher education, blended-learning, self-regulated learning, Moodle, self-assessment

\section{Autoevaluación a través de una estrategia de blended-learning para la mejora del rendimiento en una asignatura de contabilidad}

\section{Resumen}

La asignatura Contabilidad general se imparte en cinco titulaciones de grado que se ofertan en la Facultad de Ciencias Económicas y Empresariales de la Universidad de Granada. Los profesores de la asignatura han generado, de forma coordinada, materiales educativos en línea asociados a una metodología que permite que los estudiantes realicen cada año actividades de autoevaluación similares a las que están disponibles en la asignatura en su evaluación para conseguir el título de grado. Siguiendo la metodología blended-learning, que combina técnicas de educación presenciales con el uso de herramientas TIC, los estudiantes trabajan en la materia y mejoran en sus resultados académicos. En el presente 
curso se ha consultado a estudiantes de dos de los grados sobre la satisfacción general en el uso de la plataforma. De los resultados obtenidos, podemos destacar la valoración positiva de los estudiantes respecto a la utilidad de las actividades planteadas a través de la plataforma, así como su interés; también cabe reseñar la correlación positiva hallada entre el acceso a la plataforma y las calificaciones en los ejercicios de autoevaluación, y la calificación final de la asignatura.

\section{Palabras clave}

educación superior, blended-learning, aprendizaje autónomo, Moodle, autoevaluación 


\section{Introduction}

Since the University of Granada (UGR), Spain, began offering new higher education degrees in 2010, it has sought to establish an accreditation system based on the students' work (European Credit Transfer and Accumulation System, ECTS). The focus of the teaching processes implemented has changed significantly as a result, and is now centred more explicitly on the students' performance. That is one of the reasons why the teaching teams have looked for new strategies and methodologies to strengthen the fundamental role of the students, who now take control of their own learning processes. These strategies are mainly oriented towards fostering the students' active participation and trying to develop techniques for their autonomous and self-regulated learning in more flexible student-centred working environments (Kramarski \& Michalski, 2009; De Miguel, 2006).

In these processes, information and communication technologies (ICTs) are a first-rate tool, as indicated in the White Book entitled Libro Blanco de la Universidad Digital 2010 (Laviña \& Mengual, 2008). Within the current practices of Spanish universities, and according to Cabero, Llorente, and Morales (2013), it appears that both lecturers and students have adopted positive attitudes towards online methodologies in general and towards blended-learning models in particular, highlighting their usefulness, flexibility and ability to strengthen the students'involvement and participation in their learning processes. Models like these are characterised by the convergence of traditional faceto-face systems and online distance learning systems, thus forming integrated and complementary environments (Graham, 2006; Osorio, 2010).

Within the education community, there is a great deal of interest in this type of learning mode; studies have been conducted on the factors determining institutional changes (White, 2007), on technology (Fernández et al., 2011) and, more broadly, on methodology (Gikandi, Morrow, \& Davis, 2011; Cheung et al., 2010).

In this work, we shall focus on the latter of those three aspects by reviewing the methods that can be implemented via virtual environments to strengthen the students' autonomous work and formative assessment. To that end, we have presented the results of a teaching-learning experience based on doing self-assessment exercises in a blended-learning environment supported by the Moodle virtual learning environment (VLE).

\section{Theoretical framework. Formative assessment and e-learning}

Bloom (1969) established that the main purpose of formative assessment was to provide feedback and other elements to improve teaching-learning processes. Since then, many studies have focused on this type of assessment, and the essence of the definitions of it has stood the test of time. Today, however, the term usually applies to the improvement of the students' performance rather than programmes (Benett, 2011).

We can define formative assessment as a process followed by lecturers and students during instruction that provides them with feedback to adjust the process in progress, thus allowing them to improve their achievements with respect to attaining the desired learning goals (McManus, 2008). Both the instruments used and the process applied should take this definition into account to achieve what has recently been called "assessment for learning" (Cech, 2008).

In order to defend the effectiveness and value of formative assessment, we would highlight the contributions made by Black and Wiliam (2009) because of their widespread acceptance. In their work, the authors propose five key strategies for conceptualising formative assessment: 
1. Clarifying and sharing learning intentions and criteria for success.

2. Engineering effective classroom discussions and other learning tasks that elicit evidence of student understanding.

3. Providing feedback that moves learners forward.

4. Activating students as the owners of their own learning.

5. Activating students as instructional resources for one another.

In the past few years, to strengthen the students' immediate feedback and improve control over their learning, blended-learning strategies supported by an online tool to provide self-assessment activities have become more and more commonplace in higher education institutions (Sancho \& Escudero, 2012; Seluakumaran et al., 2011). Generally speaking, the students'attitudes towards strategies like these are positive. They claim to be highly satisfied with them, but have nevertheless identified some limitations, especially in relation to teacher training and technical issues (Owston, York, \& Murtha, 2013; Santamaría, Ramos, \& Sánchez-Antolín, 2012).

In the design of blended-learning strategies, the importance of the proper integration of face-to-face and virtual environments must be taken into account (Garrison \& Vaughan, 2008). Consequently, the relationships between the results obtained in the virtual environment and other important factors of the face-to-face environment must be analysed,suchasparticipationandattendance,whichdefinethestudents'engagementintheteaching-learning process.

In addition, several studies have related the use of a learning strategy based on self-assessment activities to improvements in students' performance (Ćukušić, Garača, \& Jadrić, 2014; Snodin, 2013; Lim \& Morris, 2009). However, there are few studies on the relationships between the grades obtained in online activities and the final results.

Focusing on the field of Economics and Business Studies teaching, we found that the quantity and quality of the studies on e-learning and blended learning have increased considerably in the last decade. Arbaugh et al. (2009) did an extensive review of the studies and classified them by discipline. They noted that most of them were comparative studies between fully face-to-face and e-learning or blended-learning strategies. The results of these works suggest that the outcomes of online courses are usually the same as those of fully face-to-face courses. Moreover, they highlighted the broad range of unexplored conceptual frameworks, the lack of specific discipline theories in this field, and the relative absence of a critical mass of researchers focusing on this topic, thus making it a field full of research opportunities.

The fundamental aim of this work is to analyse the impact of the use of a blended-learning strategy based mainly on the use of self-assessment activities. In accordance with everything mentioned thus far in this section, which is reinforced by the teaching staff's experience of strategies like these since 2010, the following research hypotheses for this work have been formulated:

- H1: Students of the General Accounting subject are interested in self-assessment activities and perceive that they are useful to their learning.

- H2: The integration of the virtual and face-to-face environments is represented by a positive relationship between the students' interest in and the usefulness of self-assessment activities, and their attendance at and participation in face-to-face classes.

- H3: The students'final performance in the subject is directly related to:

- H3.1: activity and the use of self-assessment activities made available to them.

- H3.2: the grades obtained in the self-assessment activities that they do on the VLE.

RUSC Vol. 11 No 2 Special Issue | Universitat Oberta de Catalunya and University of New England | Barcelona, May 2014

(a) Vanesa Gámiz, Rosana Montes and María Carmen Pérez | @ by FUOC, 2014 | Self-assessment via a blended-learning strategy to improve performance.. 


\section{Method}

The Faculty of Economics and Business at UGR offers the General Accounting subject on the curricula of six bachelor's degrees taught there; the subject falls within Accounting Studies, and there are around 850 students enrolled on it per academic year. Since the bachelor's degree was launched in 2010, the subject for all groups has been supported by a VLE to implement blended-learning strategies. The design of the content on this VLE is backed by a series of teaching innovation projects funded by UGR's Office of the Vice-Rector for Quality Assurance. Several autonomous work scripts (AWS) were developed in these projects. The scripts were made available on the VLE for the entire semester so that the students could voluntarily follow them. There were three sections: activities (in the form of multiple-choice, blank-filling and crossword-type tests, etc.), questionnaires and, finally, exams (the latter two took the form of multiple-choice tests).

In the 2012/2013 academic year, a study was conducted with 61 students, 32 of whom belonged to the bachelor's degree in Business Administration \& Management and Law group, and 29 to the bachelor's degree in Finance and Accounting group. The total number of students enrolled (both groups) was 149; the response rate was 41\%. Most of the students in the sample were aged between 19 and 20 years, and 64\% were female. The aim of the study was to evaluate the benefit of following the AWS and to test the hypotheses formulated at the start.

To the data extracted from this survey, we added other data connected with the use of the VLE and with the students' grades:

\section{- Variables included in the opinion survey}

1. Sample characteristics. In accordance with previous studies (Paechter, Maier, \& Macher, 2010), the students were characterised by: degree, age, gender, class participation and class attendance. Participation was measured on a 5-point Likert scale ( $1=$ zero; 5 = high). The same scale was used for attendance; in this case $1=$ below $20 \%, 2=20 \%$ to $40 \%, 3=41 \%$ to $60 \%, 4=61 \%$ to $80 \%$, and $5=$ above $80 \%$.

2. Content rating. In accordance with Lim and Morris (2009), a 5-point Likert scale was used to measure the interestingness and usefulness of self-assessment activities (AWS), where $1=$ not at all, and $5=$ very. Using free answer text, we analysed the following through linguistic variables: a) which of the activities the students considered the best, and b) what changes they would make to the activities available on the VLE.

\section{- Variables extracted from the VLE}

Moodle enabled us to access a variety of usage reports and activity logs. The following were used in this study: 1. The number of questionnaires that the students attempted to do and the mean grade obtained. For each of the subject topics, we developed a self-assessment questionnaire (multiple-choice, just like the final exam) with feedback. The students could choose to answer all, some or none of the questionnaires. Hence, this variable takes values between 0 and 4.

2. The number of exams that the students attempted to do and the mean grade obtained. Two exams in the form of tests with feedback were made available to the students; the exam questions were taken from previous exam papers. The students could choose to take both, one or neither of the exams. Hence, this variable takes values between 0 and 2 . 


\section{- Students' final grades variable}

This corresponds to the final grades obtained in the subject (Dowling, Godfrey, \& Gyle, 2003).

\section{Results}

Table 1 shows the descriptive statistics for the variables relating to the interestingness and usefulness of selfassessment activities available to the students on Moodle. Although the activities were optional, the students who took part in the study considered them interesting and useful. Most of the students felt that that they were averagely or quite interesting, and that they were quite or very useful.

Table 1. Descriptive statistics for the variables relating to the students' opinions of Moodle activities

\begin{tabular}{|l|c|c|c|c|c|}
\hline \multicolumn{1}{|c|}{$\begin{array}{c}\text { Number of } \\
\text { responses }\end{array}$} & Mean & $\begin{array}{c}\text { Standard } \\
\text { deviation }\end{array}$ & Minimum & Maximum \\
\hline Interestingness of AWS activities & 59 & 3.54 & 1.01 & 1 & 5 \\
\hline Usefulness of AWS activities & 59 & 3.06 & 1.06 & 1 & 5 \\
\hline
\end{tabular}

Likewise, an initial observation of these data highlights the fact that they found these self-assessment activities more useful than interesting or motivating. To contrast this observation, a Wilcoxon signed-rank test was done, the results of which $(z=-2.068$; significance $=0.039)$ showed that there were significant differences (at a significance level of 5\%) between the students' interest in the self-assessment activities and the reported usefulness of them. The first hypothesis of this work is therefore confirmed, as the students considered that these self-assessment activities were interesting and useful to their learning. In addition, it is clear that their rating of the usefulness of these activities was significantly different from their interest in them, and that they found them more useful than interesting.

Regarding the potential integration of the face-to-face and virtual environments, the following variables relating to the face-to-face environment of the subject teaching-learning process were then included in the study: class participation and class attendance. Table 2 shows the descriptive statistics for these variables and Table 3 shows the relationships between these variables and the interestingness and usefulness of self-assessment activities variables.

Table 2. Descriptive statistics for the variables relating to the face-to-face environment of the subject

\begin{tabular}{|l|c|c|c|c|c|}
\hline \multicolumn{1}{c|}{} & $\begin{array}{c}\text { Number of } \\
\text { responses }\end{array}$ & Mean & $\begin{array}{c}\text { Standard } \\
\text { deviation }\end{array}$ & Minimum & Maximum \\
\hline Class attendance & 58 & 4.62 & 0.67 & 2 & 5 \\
\hline Class participation & 57 & 3.00 & 0.98 & 1 & 5 \\
\hline
\end{tabular}

On average, the students stated that they attended more than $80 \%$ of the General Accounting subject classes. This attendance percentage was quite high. However, their class participation was quite a lot lower. The students therefore regularly attended most of the subject classes, but their class participation was only average. Thus, it could be said that face-to-face attendance does not appear to be a problem despite the lack of participation; it may therefore be necessary to assess whether it is worthwhile applying other means to manage and foster the students' class participation.

RUSC Vol. 11 No 2 Special Issue | Universitat Oberta de Catalunya and University of New England | Barcelona, May 2014

(a) Vanesa Gámiz, Rosana Montes and María Carmen Pérez | @ by FUOC, 2014 | Self-assessment via a blended-learning strategy to improve performance... 
In order to study the potential relationship between the face-to-face and virtual environment variables mentioned previously, the correlation coefficients between these variables were calculated, the results of which are shown in Table 3.

Table 3. Correlations between the variables relating to the face-to-face environment and the virtual environment (interestingness and usefulness of AWS activities)

\begin{tabular}{|l|c|c|c|c|}
\hline \multicolumn{1}{l|}{} & 1 & 2 & 3 & 4 \\
\hline 1. Class participation & 1 & & & \\
\hline 2. Class attendance & 0.078 & 1 & & \\
\hline 3. Interestingness of AWS activities & $0.463^{* *}$ & 0.131 & 1 & 1 \\
\hline 4. Usefulness of AWS activities & $0.327^{*}$ & $0.313^{*}$ & $0.590^{* *}$ & 1 \\
\hline
\end{tabular}

${ }^{*} p<0,5 ; *$ * $p<0,1$ (Spearman's Rho correlation coefficient)

Firstly, it should be noted that the students' interest in the self-assessment activities was positively and significantly correlated to the usefulness of these activities to their Accounting learning. Thus, the more useful the activities were, the more interesting the students found them, and vice versa.

Secondly, regarding the relationship between these variables and the face-to-face environment, it was found that the students' class participation was positively and significantly correlated to the students' interest in and the usefulness of self-assessment activities, and above all the former. In this respect, the students who considered the AWS activities interesting and useful were those who participated more actively in class. It should be noted that the students who did these self-assessment activities acquired a range of knowledge and a series of generic competencies that induced them to participate more in class.

Thirdly, class attendance was positively and significantly related to the perceived usefulness of the self-assessment activities. These fostered understanding and learning of the subject content worked on in class; therefore, the students who considered these AWS activities more useful were those who attended class more often.

Thus, the results obtained clearly showed the integration of the virtual and face-to-face environments because there was a positive relationship between the students' interest in and the usefulness of self-assessment activities, and their attendance at and participation in class; the second hypothesis of this work is therefore confirmed.

In order to identify which of the self-assessment activities the students considered the best for their learning, they were asked an open question in the questionnaire. The students made 91 contributions, of which exams (52\%) and questionnaires (20\%) were the AWS activities that they found best suited to their learning. Moreover, most of the students surveyed considered that no changes to these activities were necessary.

Table 4 shows that, on average, the students attempted the multiple-choice questionnaires more than half the maximum number of times allowed (four for the questionnaires and two for the exams). These data therefore support the first hypothesis, because they showed that the students were interested in repeating the exercise. Moreover, the students' performance improved at the second attempt because of feedback. This possibility was reflected in the grades obtained in the AWS, the values of which were higher than a pass (5); better grades were obtained in the exams than in the questionnaires. 
Table 4. Descriptive variables for the students' use of Moodle and of self-assessment activities

\begin{tabular}{|l|c|c|c|c|c|}
\multicolumn{1}{l|}{} & $\begin{array}{c}\text { Number of } \\
\text { responses }\end{array}$ & Mean & $\begin{array}{c}\text { Standard } \\
\text { deviation }\end{array}$ & Minimum & Maximum \\
\hline Questionnaires attemplted (out of 4) & 61 & 2.49 & 1.80 & 0 & 4 \\
\hline Questionnarie grades & 61 & 6.26 & 4.18 & 0 & 10 \\
\hline Exams attempted (out of 2) & 61 & 1.13 & 0.92 & 0 & 2 \\
\hline Exam grades & 61 & 5.54 & 4.72 & 0 & 10 \\
\hline
\end{tabular}

In order to focus on the third hypothesis concerning the students' final performance, the grades of the two groups were obtained. The distribution of these grades is shown in Figure 1. We can see that the mean grade obtained in the official June exam was 7.15.

Figure 1. Distribution of final subject grades

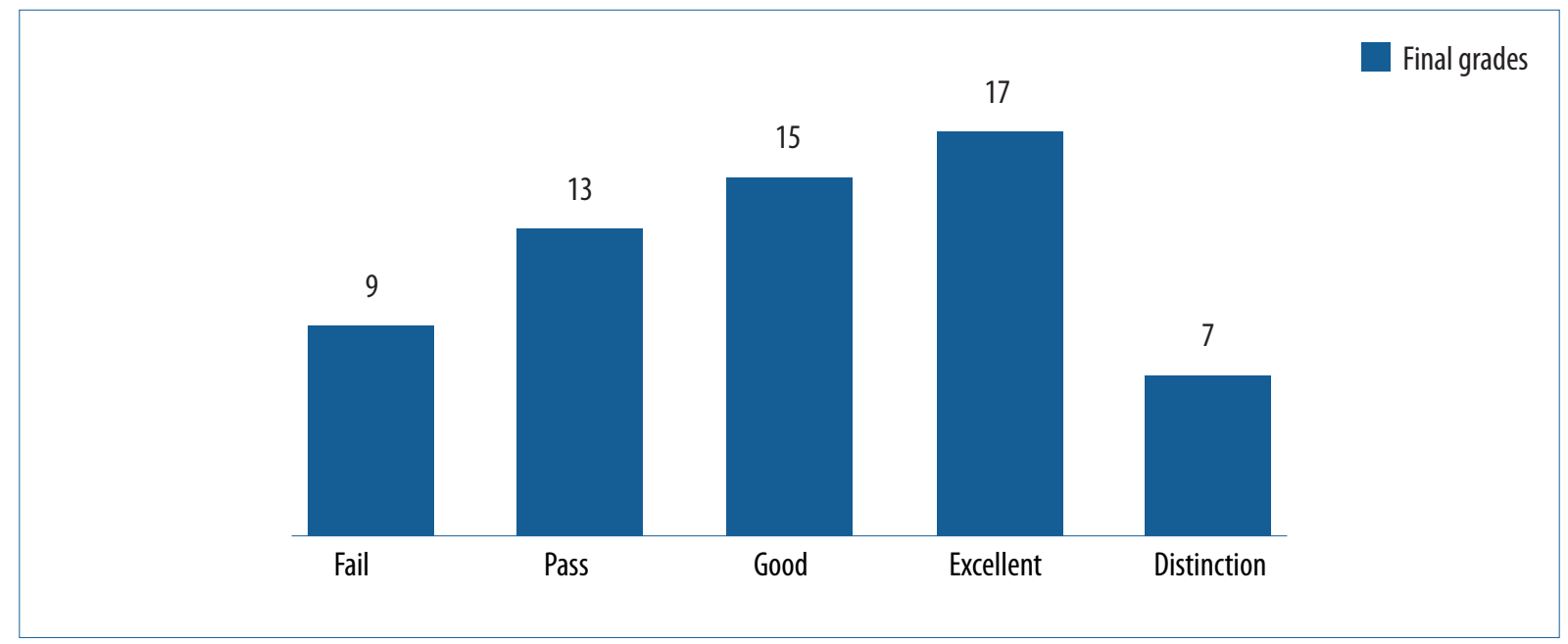

We wanted to study the relationships between the use of the VLE, the results obtained from it and the final grades. The correlation results are shown in Table 5.

Table 5. Correlations between the study variables and the final grades

\begin{tabular}{|l|c|c|c|c|c|}
\hline \multicolumn{1}{|c|}{} & 1 & 2 & 3 & 4 & 5 \\
\hline 1. Questionnaries attempted & 1 & & & & \\
\hline 2. Questionnarie grades & $0.765^{* *}$ & 1 & & & \\
\hline 3. Exams attempted & $0.759^{* *}$ & $0.637^{* *}$ & 1 & & 1 \\
\hline 4. Exams grades & $0.648^{* *}$ & $0.625^{* *}$ & $0.805^{* *}$ & 1 & 1 \\
\hline 5. Final grades & $0.253^{* *}$ & $0.291^{*}$ & $0.270^{*}$ & $0.339^{* *}$ & 1 \\
\hline
\end{tabular}

${ }^{*} p<0,5 ; * * 0,1$ (Spearman's Rho correlation coefficient) 
The questionnaires attempted and exams attempted variables, which counted the students' activity on the VLE, were positively correlated to the final grades. These data related activity and the use of self-assessment activities made available to them on the VLE to improvements in students' performance (H3.1).

Taking a look at the associations implied by the final grades (last row of Table 5), we can see that those grades were more positively related to the exam grades than to the questionnaire grades, as the students knew that the former were going to help them prepare better for the final exam in the subject. Furthermore, we can see that the final grades were also related to the rest of the variables, so we can therefore affirm that the students' effective use of activities within the VLE had an impact on the grades obtained in the self-assessment activities that they did on the VLE (H3.2) and, in turn, directly on the students' subject grades.

\section{Discussion and conclusions}

The adaption of university studies to the European Higher Education Area (EHEA) means that students have had to get more involved in the teaching-learning process. In this new educational setting, the incorporation of teaching methodologies to foster the students' autonomous work has gained in importance. The experience presented in this study was well received by the students and the lecturers. In addition, it has provided new evidence with respect to the variables that may be related to a better use and exploitation of this tool, as well as to the impact that ICT use may have on the students' academic results.

By analysing the students' opinions on their perceptions of the self-assessment activities, we have been able to show that they felt that they were interesting and useful, as other studies have done (Owston, York, \& Murtha, 2013; Santamaría, Ramos, \& Sánchez-Antolín, 2012), some of which were conducted in the field of Economics and Business Studies (López Gavira \& Omoteso, 2013; Wells, DeLange, \& Fieger, 2008). It is also interesting to note that they rated usefulness higher than interestingness. This leads us to believe that we could look for a type of tool that would raise the students' interest in activities like these, which, for example, strengthens the communication aspect or improves interaction via tools that they are familiar with, such as social networks; these could also help to improve face-to-face participation (Osgerby, 2013; Moreno, 2012).

Another interesting finding was that the students' class participation was significantly related to their opinions on the interestingness and usefulness of activities on the VLE. Hence, those students who got involved and participated in the subject considered that the AWS activities were interesting and useful. Likewise, usefulness was also correlated with class attendance, so we can therefore affirm that the activities were a complement, were directly related to the attendance aspect and were not a replacement or an unrelated aspect, as other similar studies have shown (Mitchell \& Forer, 2010; Donnelly, 2010). Thus, the relationship between the face-to-face and virtual environments of our blended-learning strategy has been demonstrated, the need for which has been suggested by Garrison and Vaughan (2008).

This study has highlighted the fact the final grades variable was significantly related to the students' activity and performance within the VLE via questionnaire and exam activities. The students who accessed the VLE more often, who did more activities and who obtained better results in them were those who ultimately obtained better grades. These findings complement those obtained from other studies that have related the use of strategies like these to improved performance (Ćukušić, Garača, \& Jadrić, 2014; Snodin, 2013; Lim \& Morris, 2009), also in the field of Economics (Novo-Corti, Varela-Candamio, \& Ramil-Díaz, 2013; Perera \& Richardson, 2010). Thus, we have been

RUSC Vol. 11 No 2 Special Issue | Universitat Oberta de Catalunya and University of New England | Barcelona, May 2014

@a Vanesa Gámiz, Rosana Montes and María Carmen Pérez | @by FUOC, 2014 | Self-assessment via a blended-learning strategy to improve performance.. 
able to confirm that there is indeed a direct relationship between the development of the students' autonomous work and their final results.

Regarding future lines of research, we intend to expand the study. The plan is to roll out this work on other degree courses, thereby collecting more data and analysing the differences and similarities between them (Arbaugh et al., 2009). The experience undertaken could also be improved by fostering communication via specific tools available either on the VLE or on other platforms that the students are more familiar and comfortable with, such as social networks, wherein collaborative work and peer assessment can be developed.

\section{References}

Bennett, R. E. (2011). Formative assessment: a critical review. Assessment in Education: Principles, Policy \& Practice, 18(1), 5-25. doi:10.1080/0969594X.2010.513678

Black, P., \& Wiliam, D. (2009). Developing the Theory of Formative Assessment. Educational Assessment, Evaluation and Accountability, 21(1), 5-31. doi http://dx.doi.org/10.1007/s11092-008-9068-5

Bloom, B. S. (1969). Some theoretical issues relating to educational evaluation. In R. W. Tyler (Ed.), Educational evaluation: new roles, new means: the 63rd yearbook of the National Society for the Study of Education (part II) (Vol. 69(2), pp. 26-50). Chicago, IL: University of Chicago Press.

Cabero, J., Llorente, M. C., \& Morales, J. A. (2013). Contributions to e-Learning from a Best Practices Study at Andalusian Universities. RUSC. Universities and Knowledge Society Journal, 10(1), 45-60. Retrieved from http:// dx.doi.org/10.7238/rusc.v10i1.1159

Cech, S. J. (2008). Test Industry Split Over "Formative" Assessment. Education Week. Retrieved from http://www. edweek.org/ew/articles/2008/09/17/04formative_ep.h28.html

Cheung, K. S., Lam, J., Lau, N., \& Shim, C. (2010). Instructional design practices for blended learning. 2010 International Conference on Computational Intelligence and Software Engineering, CiSE 2010, art. no 5676762.

Ćukušić, M., Garača, Ž., \& Jadrić, M. (2014). Online self-assessment and students' success in higher education institutions. Computers \& Education, 72, 100-109. doi:10.1016/j.compedu.2013.10.018

De Miguel, M. (Coord.) (2006). Metodologías deenseñanzay aprendizaje para el desarrollo de competencias. Orientaciones para el profesorado universitario ante el Espacio Europeo de Educación Superior. Madrid: Alianza Editorial.

Donnelly, R. (2010). Harmonizing technology with interaction in blended problem-based learning. Computers \& Education, 54(2), 350-359. doi:10.1016/j.compedu.2009.08.012

Dowling, C., Godfrey, J. M., \& Gyle, N. (2003). Do hybrid flexible delivery teaching methods improve accounting students'learning outcomes? Accounting Education, 12(4), 373-391. doi http://dx.doi.org/10.1080/09639280320 00154512

Fernández, R., Gil, I., Palacios, D., \& Devece, C. (2011). Technology platforms in distance learning: Functions, characteristics and selection criteria for use in higher education. WMSCI 2011 - The 15th World Multi-Conference on Systemics, Cybernetics and Informatics, Proceedings, 1, 309-314.

Garrison, R., \& Vaughan, H. (2008). Blended learning in higher education: Framework, principles and guidelines. San Francisco, CA: Jossey-Bass.

Gikandi, J. W., Morrow, D., \& Davis, N. E. (2011). Online formative assessment in higher education: A review of the literature. Computers \& Education, 57(4), 2333-2351. doi:10.1016/j.compedu.2011.06.004 
Graham, C. R. (2006). Blended Learning Systems: Definitions, Current Trends and Future Directions. In C. Bonk \& C. R. Graham, The Handbook of Blended Learning. Global Perspectives, Local Designs (pp. 3-21). San Francisco, CA: Pfeiffer.

Jorge Moreno, J. (2012). Using social network and dropbox in blended learning: An application to university education. Business, Management and Education, 10(2), 220. Retrieved from http://dx.doi.org/10.3846/bme.2012.16

Kramarski, B., \& Michalsky, T. (2009). Investigating Preservice Teachers'Professional Growth in Self-Regulated Learning Environments. Journal of Educational Psychology, 101(1), 161-175. doi http://dx.doi.org/10.1037/a0013101

Laviña, J., \& Mengual, L. (2008). Libro blanco de la universidad digital. Madrid: Ariel.

Lim, D. H., \& Morris, M. L. (2009). Learner and instructional factors influencing learning outcomes within a blended learning environment. Journal of Educational Technology and Society, 12(4), 282-293.

López Gavira, R., \& Omoteso, K. (2013). Perceptions of the Usefulness of Virtual Learning Environments in Accounting Education: A Comparative Evaluation of Undergraduate Accounting Students in Spain and England. Accounting Education: An International Journal, 22(5). doi:10.1080/09639284.2013.814476

McManus, S. (2008). Attributes of effective formative assessment. Washington, DC: Council for Chief State School Officers. Retrieved from http://ccsso.org/Documents/2008/Attributes_of_Effective_2008.pdf

Mitchell, P., \& Forer, P. (2010). Blended Learning: The Perceptions of First-year Geography Students. Journal of Geography in Higher Education, 34(1), 77-89. doi:10.1080/03098260902982484

Novo-Corti, I., Varela-Candamio, L., \& Ramil-Díaz, M. (2013) E-learning and face to face mixed methodology: Evaluating effectiveness of e-learning and perceived satisfaction for a microeconomic course using the Moodle platform. Computers in Human Behavior, 29(2), 410-415. Retrieved from http://dx.doi.org/10.1016/j.chb.2012.06.006

Osgerby, J. (2013) Students' Perceptions of the Introduction of a Blended Learning Environment: An Exploratory Case Study. Accounting Education: An International Journal, 22(1). doi:10.1080/09639284.2012.729341

Osorio , L. (2010). Características de los ambientes híbridos de aprendizaje: estudio de caso de un programa de posgrado de la Universidad de los Andes. RUSC. Universities and Knowledge Society Journal, 7(1). Retrieved from http://dx.doi.org/10.7238/rusc.v9i2.1285

Owston, R., York, D., \& Murtha, S. (2013) Student perceptions and achievement in a university blended learning strategic initiative. The Internet and Higher Education, 18, 38-46. Retrieved from http://dx.doi.org/10.1016/j. iheduc.2012.12.003

Pachler, N., Daly, C., Mor, Y., \& Mellar, H. (2010). Formative e-assessment: Practitioner cases. Computers \& Education, 54(3), 715-721. doi:10.1016/j.compedu.2009.09.032

Paechter, M., Maier, B., \& Macher, D. (2010). Students' expectations of, and experiences in e-learning: their relation to learning achievements and course satisfaction. Computers \& Education, 54, 222-229. doi http://dx.doi. org/10.1016/j.compedu.2009.08.005

Perera, L., \& Richardson, P. (2010) Students' Use of Online Academic Resources within a Course Web Site and Its Relationship with Their Course Performance: An Exploratory Study. Accounting Education: An International Journal, 19(6), 587-600. doi:10.1080/09639284.2010.529639

Sancho, T., \& Escudero, N. (2012). A Proposal for Formative Assessment with Automatic Feedback on an Online Mathematics Subject. RUSC. Universities and Knowledge Society Journal, 9(2), 59-79. Retrieved from http://dx.doi. org/10.7238/rusc.v9i2.1285

Santamaría, J. S., Ramos, F. J., \& Sánchez-Antolín, P. (2012). The student's perspective: teaching usages of Moodle at University. ICER/2012 Proceedings, 2968-2973. 
Seluakumaran, K., Jusof, F. F., Ismail, R., \& Husain, R. (2011). Integrating an open-source course management system (Moodle) into the teaching of a first-year medical physiology course: a case study. Advances in Physiology Education, 35(4), 369-377. doi:10.1152/advan.00008.2011

Snodin, N. S. (2013). The effects of blended learning with a CMS on the development of autonomous learning: A case study of different degrees of autonomy achieved by individual learners. Computers \& Education, 61, $209-216$. doi:10.1016/j.compedu.2012.10.004

Wells, P., DeLange, P., \& Fieger, P. (2008). Integrating a virtual learning environment into a second year accounting course: Determinants of overall student perception. Accounting and Finance, 48, 503-518. doi http://dx.doi. org/10.1111/j.1467-629X.2007.00249.x

White, S. (2007) Critical success factors for e-learning and institutional change - Some organisational perspectives on campus-wide e-learning. British Journal of Educational Technology, 38(5), 840-850. doi http://dx.doi.org/10.1111/ j.1467-8535.2007.00760.x 


\section{About the authors}

Vanesa Gámiz Sánchez

vanesa@ugr.es

Lecturer, Department of Didactics and School Organisation, University of Granada (UGR), Spain

Vanesa M. Gámiz Sánchez is a Computer Sciences Engineer and received her PhD from the University of Granada (UGR), Spain, in 2009. Since 2010, she has been a lecturer in the Department of Didactics and School Organisation in the Faculty of Educational Sciences. Previously, she worked there with a research staff training grant. She conducts her research in the fields of e-learning and the use of information and communication technologies (ICTS) in learning environments, especially in higher education. She has been part of several teaching innovation projects, and currently she is coordinating a project entitled "The e-portfolio as a learning and assessment tool. Implementation with Mahara integrated with Moodle". Also, she has been member of the research teams of several European projects on e-learning and a teacher on some technology-related training activities for university lecturers.

Departamento de Didáctica y Organización Escolar

Facultad de Ciencias de la Educación

Universidad de Granada

Campus de Cartuja, s/n

18071 Granada

Spain

Rosana Montes Soldado

rosana@ugr.es

Lecturer and Researcher, Software Engineering Department, and Head of Secretariat, Virtual Learning Centre, University of Granada (UGR), Spain.

Rosana Montes holds a PhD in Computer Science from the University of Granada (UGR), Spain, in the field of Computer Graphics and Realistic Image Synthesis, though some of her research had been related to e-learning and virtual 3D worlds. She teaches at the School of Informatics and Telecommunications Engineering, and also in the Faculty of Economics and Business at UGR. Courses are related with web design, Web 2.o., integrated software development environments and mobile applications. She has participated in several international projects funded by the European Commission and the Education, Audiovisual and Culture Executive Agency (EACEA) with the Erasmus Mundus Programme and the Lifelong Learning Programme such as "Hextlearn - Higher Education exploring ICT use for Lifelong Learning", "Mobi-Blog - the European Weblog Platform for Mobile Students", "Movinter - Enhancing Virtual Mobility to foster institutional cooperation and internationalisation of curricula" and "Wishes", and she also coordinated the project "OERtest: Testing the Feasibility of OER-Course Certification". In UGR's Virtual Learning Centre, she has played an active part in the design and implementation of AbiertaUGR, UGR's MOOC platform, and its courses. She coordinates the teacher training programmes at UGR, including the Specialisation Itineraries "Collaboration Tools in Web 2.0" and "Digital Production in the Mac OS X Environment".

Departamento de Lenguajes y Sistemas Informáticos

E. T. S. de Ingeniería Informática y de Telecomunicación

Universidad de Granada

C/ Periodista Daniel Saucedo Aranda, s/n

18071 Granada

Spain

RUSC Vol. 11 No 2 Special Issue | Universitat Oberta de Catalunya and University of New England | Barcelona, May 2014

(a) Vanesa Gámiz, Rosana Montes and María Carmen Pérez | @by FUOC, 2014 | Self-assessment via a blended-learning strategy to improve performance. . 


\section{María Carmen Pérez López}

marialo@ugr.es

Lecturer, Department of Financial Economics and Accounting, University of Granada (UGR), Spain

M. Carmen Pérez López holds a PhD degree in Economics and Business from the University of Granada (UGR), Spain. She teaches in the Faculty of Economics and Business at UGR. Among her research interests are higher education, training in entrepreneurship, corporate social responsibility, organisational culture, innovation and national and international accounting standards. She has participated as a coordinator and member of several teaching innovation projects related to the implementation of new technologies and the Moodle platform for teaching, and of ECTS on different courses taught at UGR's Faculty of Economics and Business. She is the author of several publications related to impact teaching in higher education and, specifically, to blended learning. She has also participated in many teacher training activities and has made considerable contributions to university teaching at workshops and symposia.

Departamento de Economía Financiera y Contabilidad

Facultad de Ciencias Económicas y Empresariales

Universidad de Granada

Campus de Cartuja, s/n

18071 Granada

Spain

Original title Autoevaluación a través de una estrategia de blended-learning para la mejora del rendimiento en una asignatura de contabilidad 